\title{
Pembaruan dan Harmonisasi Peraturan Perundang- undangan Bidang Lingkungan dan Penataan Ruang Menuju Pembangunan Berkelanjutan
}

\author{
Reform and Harmonization of Legislation concerning Environment and Spatial \\ Planning towards Sustainable Development
}

\author{
Maret Priyanta \\ Fakultas Hukum Universitas Padjadjaran \\ Jln. Imam Bonjol No. 21, Bandung, 40132, Jawa Barat, Indonesia. \\ Tel./Fax.+62-22-2508514E-mail: maret.priyanta@unpad.ac.id
}

Submitted: Oct 19, 2015; Reviewed: Nov 16, 2015; Accepted: Nov 21, 2015

\begin{abstract}
In an effort to achieve of state responsibility, national development carried out by all components of the nation. National development formulated and established by the government through a system of national development planning. In the implementation of development activities that use natural resources, legislation in the field of environment and spatial planning is an important aspect as the legal basis, in which the substance and purpose of the rules is not only derived from legal aspect, but also derived from sciences field environment and spatial planning. This reseacrch uses normative juridical approach, through the method of approach to legislation, the conceptual approach and an analytical approach. The scope of this normative juridical research includes a study of the principles of law, an inventory study of positive law and legal research on systematics. Regulatory issues in the field of environment and spatial planning in Indonesia in the context of sustainable development was originally rooted in the process of establishing legislation. In terms of the substance of which is set to have a tendency no longer rooted in the sciences that underlie environmental law and spatial. Concept of reform and harmonization of legislation field of environment and spatial planning in Indonesia in the context of sustainable development must be assessed in terms of the scientific approach to the whole holistic, inter and multidisciplinary and cross-sectoral to harmonize science related to the environment and spatial planning with the principles, theory and philosophy in Legal studies.
\end{abstract}

Keywords: Sustainable Development; Environmental Law; Spatial Law

\begin{abstract}
Abstrak: Dalam upaya untuk mencapai tujuan negara, pembangunan nasional dilakukan oleh semua komponen bangsa. Pembangunan nasional dirumuskan dan ditetapkan oleh pemerintah melalui suatu sistem perencanaan pembangunan nasional. Dalam pelaksanaan kegiatan pembangunan yang memanfaatkan sumber daya alam, peraturan perundang-undangan di bidang lingkungan dan penataan ruang menjadi aspek penting
\end{abstract}


sebagai landasan hukum, di mana materi muatan serta tujuan peraturan tersebut tidak hanya bersumber dari ilmu hukum, namun juga bersumber dari ilmu-ilmu pengetahuan bidang lingkungan dan tata ruang. Penelitian ini menggunakan pendekatan yuridis normatif, melalui metode pendekatan perundang-undangan, pendekatan konseptual dan pendekatan analitis. Ruang lingkup penelitian yuridis normatif ini mencakup penelitian terhadap asas-asas hukum, penelitian terhadap inventarisasi hukum positif dan penelitian terhadap sistematika hukum. Permasalahan pengaturan dalam bidang lingkungan dan tata ruang di Indonesia dalam rangka pembangunan berkelanjutan pada awalnya bersumber pada proses pembentukan peraturan perundang-undangan. Dalam hal materi muatan yang diatur memiliki kecenderungan tidak lagi bersumber pada ilmuilmu pengetahuan yang melandasi undang-undang bidang lingkungan dan tata ruang. Konsep pembaruan dan harmonisasi peraturan perundang-undangan bidang lingkungan dan tata ruang di Indonesia dalam rangka pembangunan berkelanjutan harus dikaji dari segi keilmuan dengan pendekatan utuh menyeluruh, inter dan multidisipliner serta lintas sektoral dengan mengharmoniskan ilmu terkait lingkungan dan tata ruang dengan asas, teori dan filsafat dalam ilmu hukum.

Kata Kunci: Pembangunan Berkelanjutan; Hukum Lingkungan; Hukum Tata Ruang

\section{PENDAHULUAN}

Indonesia sebagai negara yang berdaulat, memiliki tujuan dan tanggung jawab untuk “...melindungi segenap bangsa Indonesia dan seluruh tumpah darah Indonesia dan untuk memajukan kesejahteraan umum..." Tanggung jawab tersebut, diwujudkan dengan berbagai cara dan upaya. Di antaranya, pembangunan dengan tetap menjamin hak setiap warga negara untuk mendapatkan lingkungan hidup yang baik dan sehat ${ }^{2}$ bagi generasi masa kini dengan tetap memperhatikan kepentingan generasi masa mendatang.

Dalam upaya untuk mencapai tujuan negara, pembangunan nasional dilakukan oleh semua komponen bangsa. $^{3}$ Pembangunan nasional yang dirumuskan dan ditetapkan oleh pemerintah melalui suatu sistem perencanaan pada prinsipnya bertujuan untuk mendukung koordinasi

\footnotetext{
1 Pembukaan Undang-Undang Dasar Negara Republik Indonesia Tahun 1945.

Pasal 28H ayat (1) UUD 1945.

Pasal 1 angka 2 Undang-Undang Nomor 25 Tahun 2004 tentang Sistem Perencanaan Pembangunan Nasional
}

antarpelaku pembangunan; menjamin terciptanya integrasi, sinkronisasi, dan sinergi baik antardaerah, antarruang, antarwaktu, antarfungsi pemerintah maupun antara Pemerintah dan pemerintah daerah; menjamin keterkaitan dan konsistensi antara perencanaan, penganggaran, pelaksanaan, dan pengawasan; mengoptimalkan partisipasi masyarakat; dan menjamin tercapainya penggunaan sumber daya secara efisien, efektif, berkeadilan, dan berkelanjutan. ${ }^{4}$

Indonesia adalah negara hukum, sebagaimana tercantum dalam konstitusi negara Republik Indonesia tahun 1945. Hukum dalam arti peraturan perundang-undangan menjadi hal yang paling penting di Indonesia dalam rangka mencapai tujuan hukum, hal tersebut dipengaruhi sistem hukum Indonesia yang cenderung mengadopsi civil law system dengan peraturan perundangundangan sebagai sumber utama hukum di Indonesia dengan didukung sumber-sumber

\footnotetext{
4 Pasal 2 ayat (4) Undang-Undang Nomor 25 Tahun 2004 tentang Sistem Perencanaan Pembangunan Nasional.
} 
hukum lainnya seperti hukum kebiasaan dan hukum adat, hukum traktat, hukum yurisprudensi, dan hukum ilmu (pandangan ahli). ${ }^{5}$

Peraturan perundang-undangan menjadi faktor penting dalam rangka menjamin tercapainya tujuan pembangunan nasional. Peraturan Perundang-undangan adalah peraturan tertulis yang memuat norma hukum yang mengikat secara umum dan dibentuk atau ditetapkan oleh lembaga negara atau pejabat yang berwenang melalui prosedur yang ditetapkan dalam Peraturan Perundang-undangan. ${ }^{6}$

Dalam sejarah perkembangan proses pembentukan perundang-undangan di Indonesia, berbagai prosedur dalam memprakarsai sebuah undang-undang sebagai syarat formil dan pelimpahan kewenangan melalui atribusi dan delegasi ${ }^{7}$ dalam materi muatan peraturan perundang-undangan, berdampak secara tidak langsung menyebabkan penurunan kualitas sebuah produk undangundang serta menimbulkan undang-undang yang sektoral akibat tidak harmonisnya materi muatan serta kewenangan yang langsung diberikan kepada organ negara. ${ }^{8}$

Dalam awal perkembangan pengaturan pembentukan peraturan perundangundangan, diawali dengan ditetapkannya In-

5 E. Utrecht dan Moh Saleh Djindang. (1989). Pengantar dalam Hukum Indonesia. Cetakan XI. Yogyakara: PT. Ichtiar Baru, hlm.26

6 Undang-Undang Nomor 12 Tahun 2011 tentang pembentukan Peraturan Perundang-Undangan.

Diana Halim Koentoro. (2004). Hukum Administrasi Negara. Bogor: Ghalia, hlm. 26-27.

8 Dalam ketentuan UUD NRI 1945, terdapat subjek jabatan atau subjek hukum kelembagaan yang dapat dikaitkan dengan pengertian lembaga atau organ negara dalam arti yang luas diantaranya Menteri, Gubernur, dan Bupati/ Walikota dalam Jimly Asshiddiqie, Lembaga-Lembaga Negara, Organ Konstitusional Menurut UUD 1945 dalam www.jimly.com struksi Presiden Tahun $1970^{9}$ dan Keputusan Presiden Tahun $1998^{10}$ menekankan bahwa persetujuan Presiden memegang peranan penting dalam proses pembentukan peraturan perundang-undangan (Lihat Gambar 1). Hal penting terkait lainnya adalah proses tanggapan Menteri Kehakiman untuk memberikan tanggapan dari segi hukum serta rangka pengharmonian, pembulatan dan pemantapan yang akan mengonsultasikan terlebih dahulu konsep tersebut dengan Menteri Kehakiman serta Pimpinan Lembaga lainnya yang terkait. Kedua aturan dalam proses pembentukan undang-undang, menunjukan peran Menteri yang membidangi hukum dan peraturan perundang-undangan untuk memberikan arahan, tanggapan dan konsultasi dalam proses pembentukan sebuah undangundang.

Dalam perkembangannya, pada tahun $2004^{11}$ dan tahun $2011^{12}$, undang-undang tentang pembentukan peraturan perundang-undangan menyatakan bahwa pengharmonisasian, pembulatan, dan pemantapan konsepsi rancangan undang-undang yang berasal dari presiden, dikoordinasikan oleh menteri yang tugas dan tanggung jawabnya di bidang hukum dan peraturan perundang-undangan. Apabila dibandingkan secara makna, istilah koordinasi menunjukkan menurunnya kualitas harmonisasi dalam rangka pembulatan

9 Lihat Instruksi Presiden Nomor 15 Tahun 1970 tentang Tata Cara Mempersiapkan Rancangan Undang-Undang dan Rancangan Peraturan Pemerintah.

10 Lihat Keputusan Presiden Republik Indonesia Nomor 188 Tahun 1998 tentang Tata Cara Mempersiapkan Rancangan Undang-Undang

11 Undang-Undang Republik Indonesia Nomor 10 Tahun 2004 tentang Pembentukan Peraturan Perundang-undangan.

12 Undang-Undang Republik Indonesia Nomor 12 Tahun 2011 tentang Pembentukan Peraturan Perundang-undangan. 


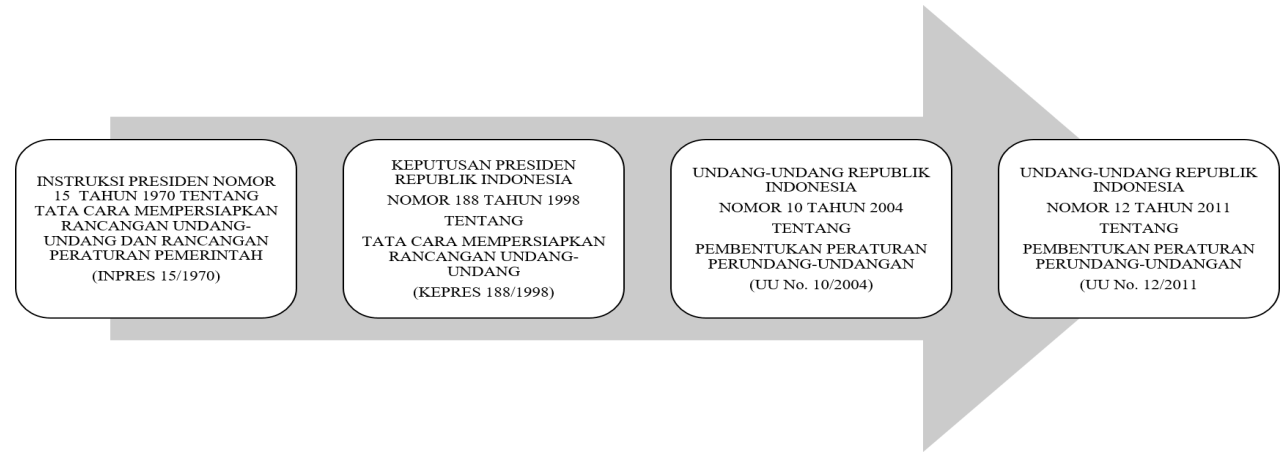

Gambar 1.

Sejarah Pengaturan tentang Pembentukan Peraturan Perundang-undangan di Indonesia

serta minimnya peran akademisi dalam proses pembentukan sebuah undang-undang.

Salah satu permasalahan dalam peraturan bidang perencanaan pembangunan, ketidakharmonisan secara jelas terlihat pada tingkatan undang-undang yaitu pengaturan tentang bentuk penetapan RPJMD. ${ }^{13}$ Ketidakharmonisan tersebut terlihat dalam Undang-Undang Nomor 25 Tahun 2004 tentang Sistem Perencanaan Pembangunan Nasional (UU SPPN) dengan UndangUndang Nomor 23 Tahun 2014 tentang Pemerintahan Daerah (UU Pemda). Dalam UU SPPN, Pasal 19 ayat (3) menyatakan bahwa RPJM Daerah ditetapkan dengan Peraturan Kepala Daerah paling lambat 3 (tiga) bulan setelah Kepala Daerah dilantik, sedangkan UU Pemda, Pasal 264 ayat (4) menyatakan bahwa Perda tentang RPJMD ditetapkan paling lama 6 (enam) bulan setelah kepala daerah terpilih dilantik. Bentuk penetapan melalui Perda dan peraturan kepala daerah memiliki perbedaan yang sangat prinsip dalam proses, waktu dan kedudukannya dalam sistem hukum nasional sehingga pengaturan yang berbeda ini menunjukan tidak dilakukannya proses

\footnotetext{
13 RPJMD merupakan Rencana Pembangunan Jangka Menengah Daerah untuk 5 (lima) tahun sebagai bagian dari RPJP.
}

harmonisasi yang layak dalam perumusan norma dalam pembentukan suatu undangundang.

Pada saat terjadinya pertentangan, tumpang tindih dalam tataran undang-undang, pemaknaan asas-asas dalam peraturan perundang-undangan menjadi sangat penting untuk menentukan aturan mana yang harus dijadikan dasar dan diacu. Pada saat aturan tidak lagi memberikan kepastian untuk menentukan sesuatu hal benar atau salah, maka ajaran-ajaran hukum (asas, teori dan filsafat) memiliki peran yang penting sebagai alat analisis. Hal tersebut menunjukkan bahwa hukum sebagai aturan (peraturan perundang-undangan) harus berlandaskan hukum sebagai ajaran dalam pembentukan dan pelaksanaannya.

Dalam pembentukan peraturan perundang-undangan bidang lingkungan dan tata ruang, dipengaruhi pula oleh materi muatan serta tujuan yang tidak hanya bersumber dari ilmu hukum, namun juga bersumber dari ilmu-ilmu pengetahuan lainnya. Dalam bidang lingkungan dilandasi oleh ilmu lingkungan dan bidang tata ruang dilandasi oleh ilmu planologi (Gambar 2).

Pelaksanaan pembangunan dalam ka itannya dengan lingkungan dan tata ruang yang selama ini cenderung tidak terencana 


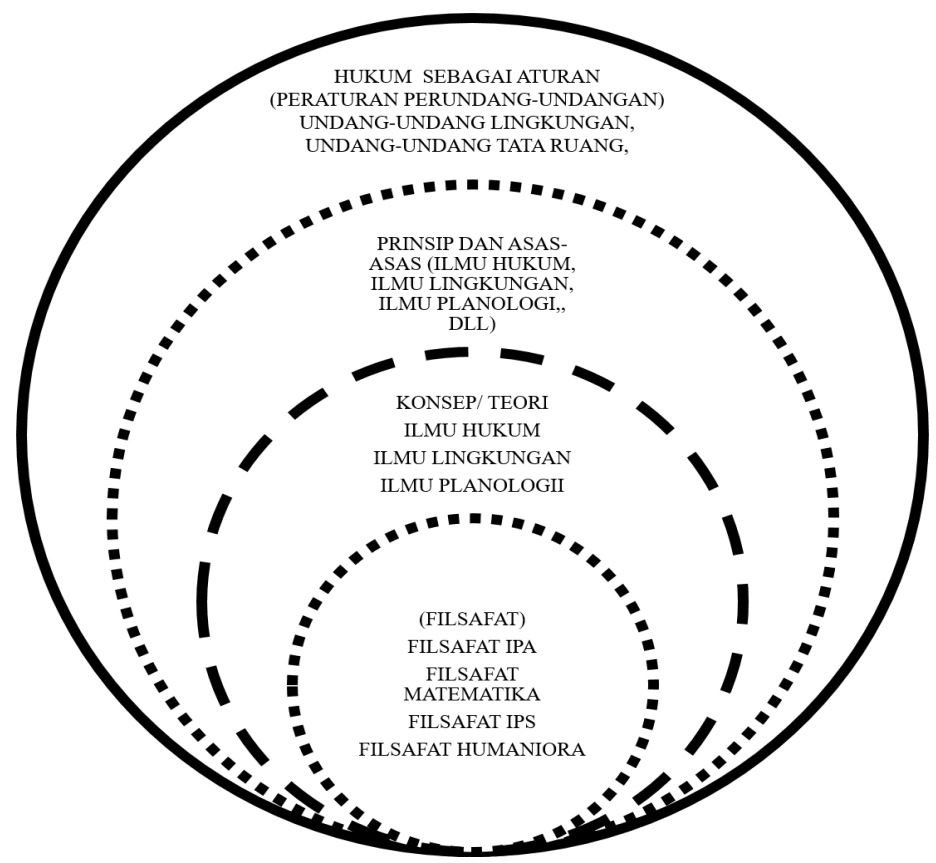

Gambar 2

Hubungan ilmu hukum dengan ilmu-ilmu pengetahuan lainnya dalam proses pembentukan Peraturan Perundang-undangan

dan tidak berkelanjutan telah berdampak pada menurunnya kualitas dan fungsi lingkungan termasuk sumber daya alam di dalamnya. Ruang sebagai wadah yang meliputi ruang darat, ruang laut, dan ruang udara, termasuk ruang di dalam bumi sebagai satu kesatuan wilayah, tempat manusia dan makhluk lain hidup, melakukan kegiatan, dan memelihara kelangsungan hidupnya ${ }^{14}$ belum dapat berfungsi secara optimal mewu judkan keharmonisan antara lingkungan alam dan lingkungan buatan, keterpaduan dalam penggunaan sumber daya alam dan sumber daya buatan dengan memerhatikan sumber daya manusia dan terwujudnya perlindungan fungsi ruang dan pencegahan dampak negatif terhadap lingkungan akibat pemanfaatan ruang.

Beberapa permasalahan dalam kaitannya dengan pembangunan berkelanjutan antara lain: Pertama, dalam bidang lingku-

\footnotetext{
14 Undang-Undang Nomor 26 Tahun 2007 tentang
} Penataan Ruang. ngan, masih terjadinya kerusakan dan kebakaran hutan, banjir, pencemaran lingkungan, dan konversi lahan produktif menjadi peruntukan lain ${ }^{15}$. Kedua, dalam bidang penataan ruang pengaturan tata ruang belum optimal, banyaknya peraturan perundang-undangan terkait ruang yang perlu disinkronkan serta rencana tata ruang belum dijadikan acuan pembangunan berbagai sektor. ${ }^{16}$ Ketiga, dalam perencanaan pembangunan, kepentingan-kepentingan ekonomi, politik menjadi permasalahan yang dihadapi, sehingga rencana yang telah disusun tidak dapat dilaksanakan secara konsisten yang mengakibatkan perencanaan pembangunan sebagai proses untuk menentukan tindakan masa depan yang tepat, melalui urutan pilihan, dengan memerhitungkan sumber daya yang

15 Chay Asdak. (2012). Kajian Lingkungan Hidup Strategis: Jalan Menuju Pembangunan Berkelanjutan. Yogyakarta: Gadjah Mada University Press, hlm.3.

16 Direktorat Tata Ruang dan Pertanahan Bappenas, Arah Kebijakan Penataan Ruang dan Pengelolaan Pertanahan Nasional 2015-2019, Jakarta, 2013. 
tersedia belum berfungsi secara optimal.

Dalam kerangka negara kesatuan, Indonesia idealnya memiliki satu sistem hukum nasional. Sistem hukum terdiri dari subsistem dan sub-sub sistem yang secara terpadu serta saling melengkapi membentuk satu sistem hukum nasional termasuk sistem hukum lingkungan sebagai salah satu sub sistemnya. Salah satu tujuan yang terkait dengan perlindungan dan pengelolaan lingkungan adalah tujuan dalam rangka menjamin tercapainya penggunaan sumber daya secara efisien, efektif, berkeadilan, dan berkelanjutan. Permasalahan dari aspek hukum, dimulai dari proses pembentukan dan pelaksanaan peraturan perundang-undangan hingga proses penegakan hukum. Permasalahan utama dalam proses pembentukan adalah tidak harmonisnya satu peraturan dengan peraturan lain yang mengatur obyek atau hal yang sama. Dalam pelaksanaannya, sinkronisasi antara satu aturan dengan aturan yang lainnya menyebabkan tumpang tindih kewenangan, sehingga menimbulkan ketidakpastian hukum.

Berdasarkan uraian permasalahan tersebut, dapat diidentifikasi permasalahan hukum dalam tulisan ini, antara lain: Pertama, kendala hukum yang ditemui dalam bidang lingkungan dan penataan ruang di Indonesia dalam rangka pembangunan berkelanjutan; Kedua, terkait konsep pembaruan dan harmonisasi peraturan perundang-undangan di bidang lingkungan dan penataan ruang dalam mewujudkan pemba-ngunan yang berkelanjutan.

\section{METODE}

Penelitian ini menggunakan pendekatan yuridis normatif, melalui metode pendekatan perundang-undangan, pendekatan konseptual dan pendekatan analitis. Ruang lingkup penelitian yuridis normatif ini mencakup penelitian terhadap asas-asas hukum, penelitian terhadap inventarisasi hukum positif dan penelitian terhadap sistematika hukum.

Penelitian ini merupakan penelitian deskriptif, yaitu penelitian yang bersifat menemukan data dan informasi terhadap variabel yang terdapat dalam materi penelitian. Objek penelitian hukum normatif ini berupa bahan hukum yang bersifat kualitatif yaitu baik bahan hukum primer (peraturan perundang-undangan), bahan hukum sekunder (bahan pustaka) maupun bahan hukum tersier (kamus hukum). Terhadap data penelitian, baik data sekunder maupun data primer, dilakukan analisis yang bersifat yuridis kualitatif dengan menggunakan metode penafsiran hukum, terutama penafsiran gramatikal, penafsiran sejarah, dan penafsiran sistematis.

\section{ANALISIS DAN PEMBAHASAN}

Hukum merupakan suatu sistem yang terdiri dari sejumlah unsur atau komponen yang selalu pengaruh memengaruhi dan terkait satu sama lain oleh satu atau beberapa asas. ${ }^{17}$ Tujuan hukum tidak dapat dilepaskan dari nilai-nilai dan falsafah hidup yang menjadi dasar hidup masyarakat yang bermuara kepada keadilan. ${ }^{18}$ Berdasarkan pandangan sistemik, maka dalam sistem hukum nasional yang berdasarkan Pancasila dan UUD 1945

17 Sunaryati Hartono. (1991). Politik Hukum Menuju Satu Sistem Hukum Nasional. Bandung: PT Alumni, hlm.56.

18 Mochtar Kusumaatmadja dan B Arief Sidharta. (2000). Pengantar Ilmu Hukum: Suatu Pengenalan Pertama Ruang Lingkup berlakunya Ilmu Hukum. Bandung: PT Alumni, hlm.4 
setiap bidang hukum yang akan merupakan bagian dari sistem hukum nasional itu wajib bersumber pada Pancasila dan UUD $1945 .{ }^{19}$

Pembaruan dimaknai dari arti katanya merupakan proses, cara, perbuatan membarui. $^{20}$ Pembaruan sistem hukum harus mengacu pada ciri sistem sebagai satu kesatuan. Adapun ciri-ciri sistem dari suatu kesatuan sistem, yaitu: Pertama, sistem adalah suatu kompleksitas elemen yang terbentuk dalam satu kesatuan interaksi (proses); Kedua, masing-masing elemen terkait dalam satu kesatuan hubungan satu sama lain saling bergantung; Ketiga kesatuan elemen yang kompleks itu membentuk satu kesatuan yang lebih besar, yang meliputi keseluruhan elemen pembentuknya itu; Keempat, keseluruhan itu menentukan ciri dari setiap bagian pembentuknya; Kelima, bagian dari keseluruhan itu tidak dapat dipahami jika ia dipisahkan, atau dipahami secara terpisah dari keseluruhan itu; Keenam, bagian-bagian itu bergerak secara dinamis secara mandiri atau secara keseluruhan dalam keseluruhan (sistem) itu. ${ }^{21}$

Syarat mutlak suatu sistem harus memiliki suatu tujuan secara pasti, agar memiliki daya gerak menuju tujuan tersebut. Dalam proses gerak suatu sistem menuju tujuannya pasti, maka terjadilah interaksi dan saling memengaruhi antara komponen menurut aturan keserasian, keselarasan dan

19 Sunaryati Hartono, Idem, hlm. 54. Lihat juga, Kelsen, Hans. (1973). General Theory of Law and State, Translated By Anders Wedberg, Russell and Russell, New York, hlm. 134.

20 Kamus Besar Bahasa Indonesia (KBBI) Offline. Diunduh pada laman website: http://pusatbahasa. diknas.go.id/kbbi/.

21 Lili Rasjidi dan I. B. Wyasa Putra. (2003). Hukum Sebagai Suatu Sistem. Cetakan kedua. Bandung: Mandar Maju, hlm 65. keseimbangan. ${ }^{22}$ Hukum yang mengatur segi-segi lingkungan hidup harus pula dipandang sebagai suatu sistem. Sistem hukum ${ }^{23}$ sebagaimana dikemukakan oleh Sunaryati Hartono $^{24}$ terdiri atas subsistem-subsistem hukum, yang antara lain adalah subsistem hukum lingkungan. Subsistem Hukum Lingkungan terdiri dari asas-asas, kaidah-kaidah dan juga meliputi lembaga-lembaga dan proses-proses guna mewujudkannya dalam kenyataan. ${ }^{25}$ Hukum lingkungan merupakan bidang hukum yang memiliki ciri khusus dalam wujud sebagai hukum yang berorientasikan pada lingkungan, di mana sifat dan hakikatnya adalah utuh menyeluruh, maka hukum lingkungan merupakan hukum berwawasan lingkungan dan bermetode utuh menyeluruh. ${ }^{26}$

Lingkungan terkait dengan unsur-unsurnya mengandung arti adanya interaksi antar unsur-unsur di dalamnya, termasuk manusia terhadap sumber daya lainnya. Dalam pandangan ekosistem yang merupakan satuan unsur-unsur fungsional di dalamnya tercakup organisme dan lingkungan abiotik yang satu terhadap yang lain, saling memengaruhi. Interaksi sebagai salah satu kaidah dalam ekosistem di mana antar unsur-unsur dalam suatu lingkungan saling memengaruhi dan bersifat timbal balik. Interaksi tersebut dapat antara unsur biotik sendiri, unsur biotik dengan abiotik, dan/atau unsur abiotik dengan abiotik lainnya. ${ }^{27}$

\footnotetext{
22 Munadjat Danusaputro. (2001). Hukum Lingkungan Buku I: Umum. Cetakan Ketiga. Bandung: Putra A. Bardin, hlm 7-8.

23 Lili Rasjidi, Op.Cit, hlm 35 - 40.

24 Sunaryati Hartono, Op.Cit., hlm. 46.

25 Mochtar Kusumaatmadja. (1976). Pembinaan Hukum dalam Rangka Pembangunan Nasional. Bandung: Bina Cipta, hlm. 14.

26 Munadjat Danusaputro, Op.Cit, hlm 87-88.

27 Amiruddin A. Dajaan Imami. (2014). Hukum Pena-
} 
Secara konseptual bahwa lingkungan terdiri atas sumber daya insani (manusia) ${ }^{28}$, sumber daya alam, dan sumber daya buatan/ budaya sebagai interaksinya. ${ }^{29}$ Manusia dan aktivitasnya memengaruhi lingkungan, pun sebaliknya, manusia juga dipengaruhi oleh lingkungannya. Begitupula halnya dengan jasad-jasad hidup lainnya, oleh sebab itu, apa yang dimaksudkan dengan lingkungan bukan hanya lingkungan fisik dan biologi melainkan meliputi lingkungan sosial, ekonomi, budaya, politik dan pertahanan keamanan. Manusia dan aktivitasnya yang mempengaruhi lingkungan sebagai suatu interaksi memunculkan sumber daya budaya/ buatan. ${ }^{30}$

Berkenaan dengan kedudukan sumber daya alam sebagai bagian dari lingkungan, dapat dimaknai bahwa sumber daya alam alamiah seperti hutan, air, tambang, minyak, gas bumi dan sebagainya merupakan sumber daya alam dimana saat berbicara lingkungan terdapat interaksi antara unsur-unsurnya termasuk sumber daya alam yang secara kesatuan ekosistem membentuk lingkungan. Sehingga peraturan perundang-undangan yang mengatur sumber daya alam harus bersumber kepada peraturan perundang-undangan di bidang lingkungan dengan diwadahi ruang, sebagaimana pengaturan peraturan

taan Ruang Kawasan Pesisir: Harmonisasi dalam Pembangunan Berkelanjutan. Bandung: Logoz Publishing, hlm.44-45; Lihat juga, Ida Bagus Wyasa Putra. (2003). Hukum Lingkungan Internasional: Perspektif Bisnis Internasional. Bandung: Refika Aditama, hlm.2; Lihat juga, Andi Hamzah. (2005). Penegakan Hukum Lingkungan. Jakarta: Sinar Grafika, hlm.5

28 Sumber daya Insani meliputi IQ (Intellegence Qoutient), SQ (Spiritual Qoutient) dan EQ (Emotional Qoutient).

29 Bandingkan dengan Amiruddin A. Dajaan Imami, Op.Cit, hlm.62.

30 Munadjat Danusaputro, Op.Cit., hlm. 187 perundang-undangan bidang tata ruang.

Dalam ekologi, lingkungan secara ilmiah disebut ekosistem dan manusia berada sebagai salah satu bagian (subsistemnya). Lingkungan hidup sebagai suatu ekosistem terdiri atas berbagai subsistem yang mempunyai aspek sosial, budaya, ekonomi dan geografi serta corak ragam yang berbeda serta mengakibatkan daya tampung dan daya dukung lingkungan yang berlainan. Keselarasan, keserasian dan keseimbangan daya tampung dan daya dukung akan meningkatkan ketahanan subsistem, yang berarti juga meningkatkan ketahanan lingkungan secara keseluruhan. Sumber daya alam merupakan unsur dari lingkungan hidup yang mendukung kehidupan. Jumlah sumber daya alam yang terbatas merupakan kendala bagi pembangunan nasional. ${ }^{31}$

Pembangunan memerlukan sumber daya, keterbatasan sumber daya serta tanggung jawab negara untuk kepentingan generasi masa kini dan masa mendatang menjadi hal yang penting berkenaan dengan hal tersebut konsep Pembangunan berkelanjutan disepakati dalam Konferensi Rio de Janeiro Tahun 1992 menjadi hal yang perlu untuk dipertimbangkan dalam memadukan pembangunan dengan sumber daya alam. Pembangunan berkelanjutan didefinisikan oleh Komisi Brundland yaitu World Commision on Environment and Development (WCED) sebagai pembangunan yang memenuhi kebutuhan sekarang tanpa mengurangi kemampuan generasi-generasi mendatang memenuhi kebutuhannya sendiri, sebagaimana tercantum

\footnotetext{
31 Moh. Soerjani, Rofiq Ahmad, Rozy Munir (Ed). (1987). Lingkungan: Sumberdaya Alam dan Kependudukan dalam pembangunan. Jakarta: UI Press, hlm.18
} 
dalam laporan Komisi Brundland "Our Common Future" pada tahun 1987.32 WCED mendekati masalah lingkungan dan pembangunan dari enam sudut pandang, antara lain: keterkaitan (interdependency), berkelanjutan (sustainability), pemerataan (equity), sekuriti dan resiko lingkungan, pendidikan dan komunikasi, dan kerjasama internasional. ${ }^{33}$

Proses pembangunan berkelanjutan bertumpu pada kondisi sumber daya alam, kualitas lingkungan dan faktor kependudukan. Mengingat ketiga faktor di atas, maka upaya pembangunan berwawasan lingkungan perlu memelihara keutuhan fungsi tatanan lingkungan agar lingkungan dapat secara berlanjut menopang proses pembangunan secara terus menerus dari generasi ke generasi untuk meningkatkan kualitas manusia Indonesia ${ }^{34}$.

Sistem hukum lingkungan sebagai subsistem hukum nasional meliputi peraturan perundang-undangan yang secara hierarki terdiri atas Undang Undang Dasar 1945, Undang-Undang/Peraturan Pemerintah Pengganti Undang-Undang, Peraturan Pemerintah, Peraturan Presiden, Peraturan Daerah Provinsi dan Peraturan Daerah Kabupaten/Kota. Sejalan dengan hal tersebut, "Stufen bau des Recht Theory" yang dikemukakan Adolf Merkel dan Hans Kelsen yang menyatakan bahwa:

"The norm determining the creation of an other norm is the superior, the norm created according to this

32 Bandingkan Koesnadi Hardjasoemantri, Kuliah Umum Program Pascasarjana Ilmu Hukum Universitas Lambung Mangkurat, 31 Mei 2004.

33 Bandingkan Koesnadi Hardjasoemantri, Op.Cit, hlm 14.

34 Surna T. Djajadiningrat. (1994). Artikel: Pembangunan Berkelanjutan dan Berwawasan Lingkungan, Jurnal Hukum Lingkungan, ICEL. regulation the inferior norm. The legal order, especially the legal order the personification of which is the state, is therefore not a system of norm coordinated to each other, standing to speak side by side on the same level, but hierarchy of different levels of norms".

Hukum itu bersifat hierarkis, artinya ketentuan yang paling di bawah bersumber dari ketentuan yang lebih atas derajatnya. ${ }^{35}$ Dalam teorinya tersebut, terdapat kaidah dasar dari suatu tata hukum nasional yang merupakan suatu kaidah fundamental. Kaidah dasar tersebut disebut grundnorm yang merupakan asas-asas hukum yang bersifat abstrak, bersifat umum atau hipotesis. ${ }^{36}$

Beragam undang-undang yang mengatur berbagai persoalan, menuntut pemahaman dan kemampuan untuk mendudukkan undang-undang sesuai dengan tujuan dan fungsinya. Berkenaan dengan hal tersebut, asas-asas yang harus dapat dipahami dalam menentukan undang-undang yang digunakan apabila terdapat indikasi ketidakharmonisan. Purnadi Purbacaraka dan Soerjono Soekanto, berpandangan bahwa pada asasnya, Pertama, bahwa undang-undang tidak berlaku surut, asas ini bertujuan agar terwujudnya kepastian hukum. Kedua,bahwa undang-undang yang dibuat oleh penguasa yang lebih tinggi mempunyai kedudukan yang lebih tinggi, atau yang dikenal sebagai asas hirarki, sebagaimana pandangan Amiroedidin Syarif. Ketiga, bahwa undangundang yang bersifat khusus menyampingkan undang-undang yang bersifat umum (lex

35 Bandingkan dengan Hans Kelsen, Op.Cit, hlm. 134. diterjemahkan oleh penulis.

36 Rosjidi Ranggawidjaja. (1998). Pengantar Ilmu Perundang-undangan Indonesia. Bandung: Mandar Maju, hlm.26. 
specialis derogat legi generali). Dalam implementasinya, asas ini masih menimbulkan banyak perdebatan atau perbedaan pendapat berkenaan dengan makna khusus, apakah makna khusus ini dimaknai khusus dari kewenangan, judul undang-undang atau khusus dari kompetensi materi muatan dalam undang-undang yang merujuk pada urusan yang menjadi kewenangan suatu organ negara $^{37}$ dalam arti luas. Keempat, bahwa Undang-undang yang berlaku belakangan membatalkan undang-undang yang berlaku sebelumnya (Lex posterior derogate legi priori), hal yang penting dalam asas ini adalah judul ataupun materi muatannya harus sama, dalam arti membatalkan materi muatan aturan yang sebelumnya. ${ }^{38}$

Berkenaan dengan fungsi hukum dalam pembangunan, Mochtar Kusumaatmadja menyatakan bahwa hukum harus berfungsi dalam masyarakat yang sedang membangun, sehingga hukum harus dapat membantu proses perubahan masyarakat. Pandangan bahwa dengan ahli hukum tak dapat membuat revolusi, dapat dibantah dengan perkembangan konsep Law as a tool of Social Engineering yang dikembangkan oleh Roscoe Pound di Amerika Serikat dimana hukum dijadikan alat untuk perubahan-perubahan masyarakat. ${ }^{39}$ Mochtar Kusumaatmadja terinspirasi dengan konsep tersebut dan khusus di Indonesia, hukum sebagai

37 Dalam ketentuan UUD 1945, terdapat subjek jabatan atau subjek hukum kelembagaan yang dapat dikaitkan dengan pengertian lembaga atau organ negara dalam arti yang luas dalam Jimly Asshiddiqie, Lembaga-Lembaga Negara, Organ Konstitusional Menurut UUD 1945 dalam www. jimly.com

38 Rosjidi Ranggawidjaja, Loc.Cit, Mandar Maju, 1998

39 Mochtar Kusumaatmadja, Fungsi dan Perkembangan..., Op.Cit, hlm.11. sarana dalam perubahan masyarakat, makna sarana yang dimaksud Mochtar adalah peraturan perundang-undangan.

Pandangan Mochtar dalam tulisan beliau pada tahun 1972, dinyatakan bahwa berkenaan dengan perubahan maupun ketertiban (atau keteraturan) merupakan tujuan kembar daripada masyarakat yang sedang membangun maka hukum menjadi suatu alat yang tak dapat diabaikan dalam proses pembangunan. Dalam paparan konsep, beliau memperkenalkan mengenai definisi hukum sebagaimana dinyatakan bahwa hukum tidak saja merupakan keseluruhan asas-asas dan kaidah-kaidah yang mengatur kehidupan manusia dalam masyarakat, melainkan meliputi pula lembaga-lembaga (institutions) dan proses-proses (process) yang mewujudkan berlakunya kaidah-kaidah itu dalam kenyataan. ${ }^{40}$

Berkenaan dengan pandangan tersebut, Otje Salman menjabarkan bahwa dalam definisi hukum Mochtar Kusumaatmadja, asas dan kaidah mencerminkan pengaruh aliran positivism hukum. Istilah asas berarti nilai moral tertinggi, sedangkan kaidah merupakan patokan tentang perilaku yang seharusnya, yang berisi perintah, larangan dan kebolehan. Sedangkan istilah lembaga dan proses mencerminkan pengaruh aliran sosiological jurisprudence dan pragmatic legal realism. Pengertian lembaga dan proses mengandung makna, baik dalam bidang pengadilan maupun di luar pengadilan. ${ }^{41}$

Dalam konsep bekerjanya hukum, guna mewujudkannya dalam kenyataan.

$40 \quad$ Ibid, hlm.11.

${ }^{41}$ Otje Salman. (2009). Filsafat Hukum: Perkembangan dan Dinamika Masalah. Bandung: Refika Aditama, hlm.26-27. 
Bekerja/berfungsinya hukum sebagai pandu (membina, mengawasi dan menjamin) proses pembangunan (segala bidang) agar sampai di tujuan nasional. Dalam konsep ini, hukum harus berdiri di depan dan menjadi penunjuk arah bagi terselenggaranya pembangunan nasional (di segala bidang) secara tertib dan teratur (bukan hanya pembangunan hukum). Sarana pendukung manajemen pemerintahan yang modern berupa rencana pembangunan sebagai bagian dari sistem perundangundangan, partisipasi masyarakat dalam proses pengambilan keputusan; serta sikap tindak pemerintah/masyarakat harus dapat dipertanggungjawabkan secara hukum.

Dalam perencanaan pembangunan serta dalam pembaruan dan harmonisasi peraturan perundang-undangan bidang lingkungan dan penataan ruang yang berkelanjutan, perlu diselaraskan untuk mencapai tujuan pembangunan dan lingkungan berdasarkan peraturan perundang-undangan. Beberapa hal perlu dilakukan pembaruan antara lain: Pertama, hukum harus berdiri di depan, menentukan arah bagi terselenggaranya pembangunan yang diwujudkan melalui perencanaan terhadap pembangunan yang didasarkan kepada hukum dalam arti peraturan perundang-undangan dengan terus melakukan peningkatan kualitas dalam proses penyusunan rencana. Kedua, peraturan perundang-undangan di bidang lingkungan dan penataan ruang harus bersumber pada ilmu-ilmu terkait lainnya dengan pendekatan utuh menyeluruh (multidisipliner dan interdisipliner). Pada hakikatnya, sumber-sumber daya merupakan bagian dari lingkungan, dimana interaksi unsur-unsurnya membentuk satu kesatuan yang saling memengaruhi, sehingga undang-undang yang mengatur pengelolaan sumber daya harus bersumber dan mendukung tujuan undang-undang lingkungan sebagai umbrella provision dengan pendekatan fungsional. Ketiga, dalam rangka mencapai tujuan pembangunan berkelanjutan, harus diupayakan hubungan pengaturan yang harmonis dan serasi antara penataan ruang ${ }^{42}$ yang mewadahi lingkungan ${ }^{43}$ serta kegiatan pembangunan ${ }^{44}$ yang memiliki kecenderungan memanfaatkan sumber-sumber daya di dalamnya termasuk sumber daya alam. Keempat, pemahaman dan pembaruan pemaknaan asas-asas dalam peraturan perundang-undangan terutama penerapan asas yang menyatakan bahwa undang-undang yang bersifat khusus menyampingkan undang-undang yang bersifat umum (lex specialis derogat legi generali). Undang-undang yang bersifat khusus sebaiknya dimaknai bahwa manakala terdapat suatu materi yang mengatur hal yang sama dalam dua atau lebih undang-undang, maka materi yang harus diacu adalah undang-undang yang kompetensi yang didasakan pada ilmu pengatahuan serta kewenangan yang selaras dengan judul dan materi muatan suatu undang-undang. Dengan demikian, undang-undang menge-

42 Lihat, Undang-Undang Nomor 26 Tahun 2007 tentang Penataan Ruang dinyatakan "Ruang adalah wadah yang meliputi ruang darat, ruang laut, dan ruang udara, termasuk ruang di dalam bumi sebagai satu kesatuan wilayah, tempat manusia dan makhluk lain hidup, melakukan kegiatan, dan memelihara kelangsungan hidupnya."

43 Lihat, Undang-Undang Nomor 32 Tahun 2009 tentang Perlindungan dan Pengelolaan Lingkungan Hidup, "Lingkungan hidup adalah kesatuan ruang dengan semua benda, daya, keadaan, dan makhluk hidup, termasuk manusia dan perilakunya, yang mempengaruhi alam itu sendiri, kelangsungan perikehidupan, dan kesejahteraan manusia serta makhluk hidup lain."

44 Lihat, Undang-Undang Nomor 25 Tahun 2004 tentang Sistem Perencanaan Pembangunan Nasional. 
nai lingkungan, tata ruang, perencanaan (pembangunan) yang telah disusun melalui proses kajian ilmu-ilmu selain ilmu hukum, sejauh mengenai lingkungan, penataan ruang dan perencanaan, harus tetap bersumber pada ilmu-ilmu yang melandasinya, termasuk prioritas untuk menjadikannya dasar pengaturan dalam peraturan perundang-undangan.

\section{PENUTUP}

Permasalahan pengaturan dalam bidang lingkungan dan penataan ruang di Indonesia dalam rangka pembangunan berkelanjutan bersumber pada proses pembentukan peraturan perundang-undangan terkait. Dalam hal materi muatan yang diatur memiliki kecenderungan tidak lagi bersumber pada ilmu-ilmu pengetahuan yang melandasi undang-undang bidang lingkungan dan tata ruang. Setiap ilmu pengetahuan mempunyai tujuan yang ingin dicapai, tujuan tersebut harus diselaraskan dengan tujuan ilmu hukum dalam rangka memberikan ketertiban, kepastian dan keadilan dalam masyarakat. Kegiatan pembangunan dalam memberikan perubahan serta dalam rangka meningkatkan kualitas hidup manusia harus tetap memertimbangkan aspek lingkungan dan aspek tata ruang untuk tetap mewujudkan pelestarian fungsi lingkungan dan fungsi ruang secara berkelanjutan untuk kepentingan generasi masa kini dan masa mendatang.

Konsep pembaruan dan harmonisasi peraturan perundang-undangan bidang lingkungan dan penataan ruang dalam rangka pembangunan berkelanjutan harus bersumber pada asas, teori dan filsafat yang melandasi pembentukan suatu undang-undang.
Hukum sebagai aturan (perundang-undangan) secara operasional tidak dapat lepas dari sumber-sumber ilmu pengetahuan dan filsafat yang melandasi pembentukannya, sehingga manakala aturan tidak dapat memberikan kepastian dan keadilan, asas, teori dan filsafat menjadi hal yang penting dalam rangka pembaruan dan harmonisasi untuk memberikan pemaknaan secara ilmiah terhadap suatu permasalahan yang ditimbulkan sejak proses pembentukan hingga pelaksanaan sebuah undang-undang.

Pembaruan dan harmonisasi peraturan perundang-undangan bidang lingkungan dan penataan ruang di Indonesia dalam rangka pembangunan berkelanjutan harus bersumber dari asas, teori dan filsafat. Berkenaan dengan teori yang digunakan dalam ilmu hukum, teori yang dikembangkan oleh ahliahli hukum Indonesia sebaiknya diprioritaskan. Hal tersebut dikarenakan dalam pembentukan suatu aturan harus dipertimbangkan karakteristik bangsa Indonesia agar aturan yang ditetapkan dapat dengan mudah dilaksanakan. Peraturan perundang-undangan bidang lingkungan dan tata ruang harus menjadi dasar dalam perencanaan pembangunan. Hukum harus berdiri di depan menentukan arah pembangunan demi terwujudnya tujuan negara untuk keadilan generasi masa kini dan masa mendatang.

\section{BIBLIOGRAFI}

Amiruddin A. Dajaan Imami. (2014). Hukum Penataan Ruang Kawasan Pesisir: Harmonisasi dalam Pembangunan Berkelanjutan. Bandung: Logoz Publishing.

Andi Hamzah. (2005). Penegakan Hukum 
Lingkungan. Jakarta: Sinar Grafika.

Chay Asdak. (2012). Kajian Lingkungan Hidup Strategis: Jalan Menuju Pembangunan Berkelanjutan. Yogyakarta: Gadjah Mada University Press.

Diana Halim Koentoro. (2004). Hukum Administrasi Negara. Bogor: Ghalia.

E. Utrecht dan Moh Saleh Djindang. (1989). Pengantar dalam Hukum Indonesia. Cetakan XI. Yogyakara: PT. Ichtiar Baru.

Ida Bagus Wyasa Putra. (2003). Hukum Lingkungan Internasional: Perspektif Bisnis Internasional. Bandung: Refika Aditama.

Lili Rasjidi dan I. B. Wyasa Putra. (2003). Hukum Sebagai Suatu Sistem. Cetakan kedua. Bandung: Mandar Maju.

Mochtar Kusumaatmadja. (1976). Pembinaan Hukum dalam Rangka Pembangunan Nasional. Bandung: Bina Cipta.

Mochtar Kusumaatmadja dan B Arief Sidharta. (2000). Pengantar Ilmu Hukum: Suatu Pengenalan Pertama Ruang Lingkup berlakunya Ilmu Hukum. Bandung: PT Alumni.

Moh. Soerjani, Rofiq Ahmad, Rozy Munir (Ed). (1987). Lingkungan: SumberDaya Alam dan Kependudukan dalam pembangunan. Jakarta: UI Press.

Munadjat Danusaputro. (2001). Hukum Lingkungan Buku I: Umum. Cetakan Ketiga. Bandung: Putra A. Bardin.

Otje Salman. (2009). Filsafat Hukum:
Perkembangan dan Dinamika Masalah. Bandung: Refika Aditama.

Rosjidi Ranggawidjaja. (1998). Pengantar Ilmu Perundang-undangan Indonesia. Bandung: Mandar Maju.

Sunaryati Hartono, Idem, hlm. 54. Lihat juga, Kelsen, Hans. (1973). General Theory of Law and State, Translated By Anders Wedberg, Russell and Russell, New York.

Sunaryati Hartono. (1991). Politik Hukum Menuju Satu Sistem Hukum Nasional. Bandung: PT Alumni.

Surna T. Djajadiningrat. (1994). Artikel: Pembangunan Berkelanjutan dan Berwawasan Lingkungan, Jurnal Hukum Lingkungan, ICEL.

\section{Sumber lainnya:}

Direktorat Tata Ruang dan Pertanahan Bappenas, Arah Kebijakan Penataan Ruang dan Pengelolaan Pertanahan $\mathrm{Na}$ sional 2015-2019, Jakarta, 2013.

Jimly Asshiddiqie, Lembaga-Lembaga $\mathrm{Ne}$ gara, Organ Konstitusional Menurut UUD 1945. Dikutip dalam: www.jimly.com

Kamus Besar Bahasa Indonesia (KBBI) Offline. Diunduh pada laman website: http://pusatbahasa.diknas.go.id/kbbi/.

Koesnadi Hardjasoemantri, Kuliah Umum Program Pascasarjana Ilmu Hukum Universitas Lambung Mangkurat, 31 Mei 2004. 